\title{
Diet Composition of Two Temperate Calcareous Sponges: Leucosolenia echinata and Leucetta sp. from the Wellington South Coast, New Zealand
}

\author{
Alejandra Perea-Blázquez ${ }^{*}$, Kylie Price $^{2}$, Simon K. Davy ${ }^{1}$ and James J. Bell ${ }^{1}$ \\ ${ }^{I}$ Centre for Marine Environmental and Economic Research, School of Biological Sciences, Victoria University of \\ Wellington, P.O. Box 600, Wellington, New Zealand \\ ${ }^{2}$ Flow Cytometry Suite, Malaghan Institute of Medical Research, Wellington, New Zealand
}

\begin{abstract}
Sponges are an important component of benthic ecosystems in New Zealand, and as suspension feeders they can process large volumes of water meaning that their interaction with the water column is likely to be of great importance. Our research focuses on the functional role of sponges as suspension feeders in temperate rocky subtidal ecosystems on the Wellington South Coast, New Zealand. We investigated the diet composition of two common species of calcareous sponges (Leucosolenia echinata and Leucetta sp.) by identifying and quantifying food particles from water samples using flow cytometry, and estimating the removal efficiency for these species. The natural diet of both species included heterotrophic bacteria, Prochlorococcus sp. and Synechococcus sp., similar to that previously reported for demosponges. We found significant differences in the number of picoplanktonic organisms present between ambient and exhalent water for both study species. Prochlorococcus and Synechococcus were removed with the highest efficiency irrespective of sponge species (52-57\%). Both species had similar overall removal efficiencies, but we detected significant differences in the removal rates of the three types of bacteria in each species. Our study is the first to investigate the natural diet of calcareous sponges in temperate rocky subtidal reefs using flow cytometry and we provide evidence for differences in the diets of calcareous sponges and demosponges.
\end{abstract}

Keywords: New Zealand, diet composition, calcareous sponges.

\section{INTRODUCTION}

Sponges, as suspension feeders, depend on food in the water column [1], and have evolved mechanisms to capture food that is highly diluted within seawater and too small to be detected and captured individually [2]. Benthic suspension feeders in shallow-water marine ecosystems are capable of transferring large quantities of material from the overlying water column to the sea floor [3]. The high abundance of sponges in many benthic habitats is therefore likely to result in a considerable interaction between sponges and the water column, with sponges being an important link to higher trophic levels [4].

Although the functional roles of sponges on coral reefs (e.g. bioeroders, reef consolidators/stabilisers) have been well described [e.g. 4-6], there are far fewer studies focusing on the functional roles that sponges play in temperate regions. Furthermore, very little is known about the New Zealand sponge fauna and its ecology compared with other temperate regions, such as southern Australia and northern Europe. Sponges are important components of benthic ecosystems in New Zealand and due to their high abundance, high filtration capacity, and a heterogeneous diet, sponges may be important in influencing nutrient dynamics in New Zealand coastal ecosystems [7].

*Address correspondence to this author at the Centre for Marine Environmental and Economic Research, School of Biological Sciences, Victoria University of Wellington, P.O. Box 600, Wellington, New Zealand; E-mail: Alejandra.Perea@vuw.ac.nz
While the feeding ecology of tropical demosponges has been well studied [8-10], there are few studies examining the natural diet of marine sponges in temperate regions [11,12], and to our knowledge only one study has estimated the removal efficiency of a calcareous sponge [13]. Wilkinson et al. [13] investigated the removal efficiencies of four tropical sponges from Australia including one calcareous species (Pericharax heteroraphis), which was measured by collecting in situ water samples and analysing them using the pourplate counting technique. The authors found that all study species efficiently filtered heterotrophic bacteria from the ambient water with removal efficiencies of between $98 \%$ and $99 \%$ for the demosponges, and $95.5 \%$ for the calcareous sponge [13]. To date, there have been no studies on sponge feeding for New Zealand species.

In the last two decades, flow cytometry has become a valuable tool in aquatic and environmental microbiology, and has largely been used to determine cell numbers, cellsize distribution, and additional biochemical and physiological characteristics of individual cells from different populations of picoplankton (plankton $<2 \mu \mathrm{m}$ in size) $[14,15]$. The prokaryotic fraction of natural marine pelagic communities is composed of both heterotrophic and autotrophic organisms [16]. These micro-organisms have been discriminated using flow cytometry as follows: Prochlorococcus $(0.6-0.8 \mu \mathrm{m}$ size), photosynthetic organisms that harvest light using divinyl-chlorophylls $a$ and $b$ [17] and only emit red fluorescence; Synechococcus ( $1 \mu \mathrm{m}$ size), photosynthetic prokaryotes characterised by the dual fluorescence of their pigments. The other major prokaryotic group is the diverse heterotrophic bacteria (ranging between $0.2-2 \mu \mathrm{m}$ in size), charac- 


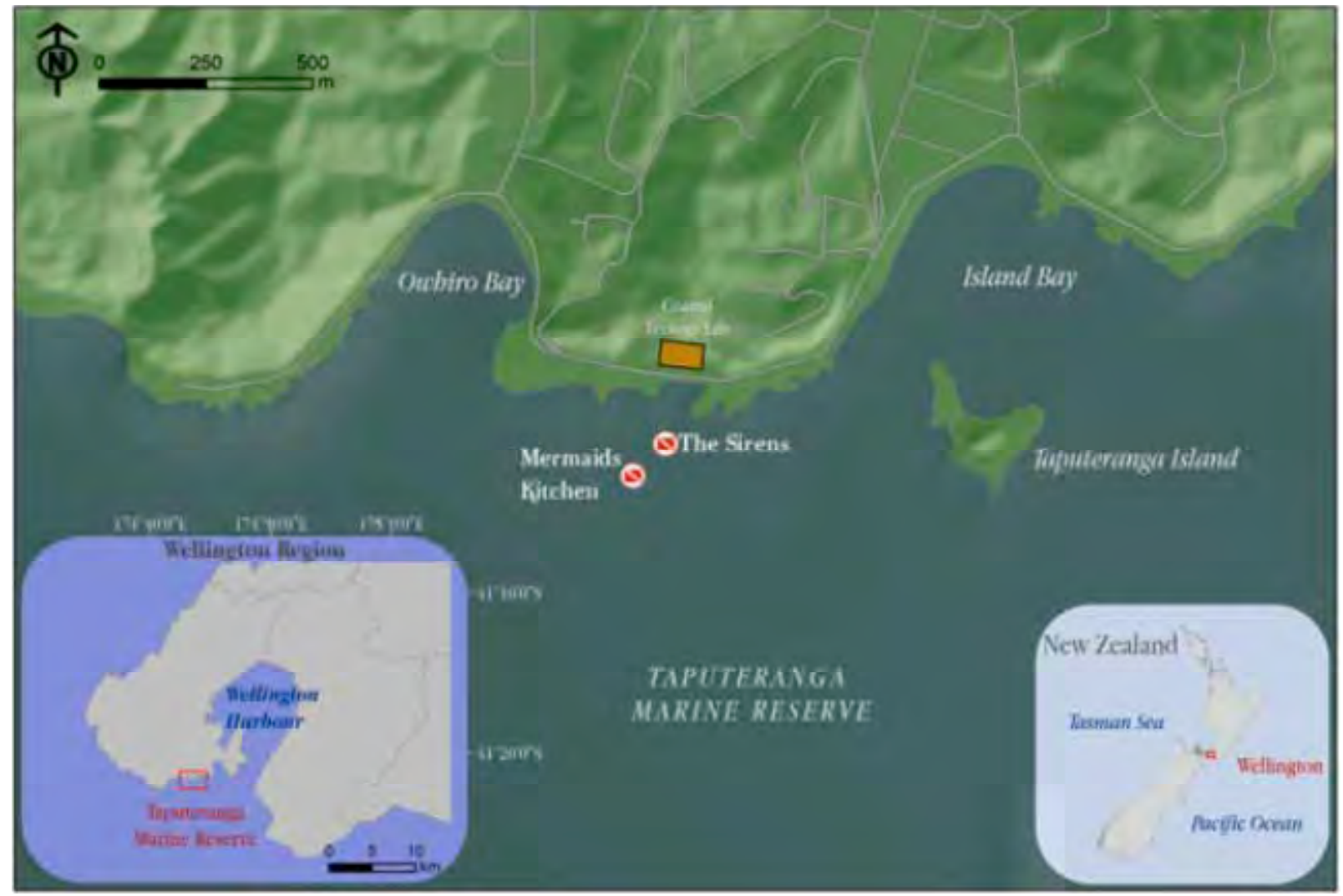

Fig. (1). Map of the south coast of Wellington showing the two study sites, Mermaids Kitchen and The Sirens, within Taputeranga Marine Reserve, Wellington New Zealand. This map was compiled by Benjamin Magaña-Rodríguez on June 2009.

Data sources: New Zealand Territorial Authority data, Wellington Digital Elevation Model image. Projection and Datum: NZMG 1949.

terised from flow cytometry by the absence of photosynthetic pigments and therefore autofluorescence.

The aim of our study was to identify and quantify food particles from water samples collected in situ from two species of calcareous sponges, Leucosolenia echinata and Leucetta sp., and to investigate the populations of microorganisms that these sponges are removing from the water column. These species are particularly abundant and widely distributed along the south coast of the Wellington region and therefore potentially important in the cycling of food particles between the water column and the overlying rocky subtidal habitats.

\section{MATERIALS AND METHODS}

\section{Study sites}

We examined sponge picoplankton removal at two sites within the Taputeranga Marine Reserve on the south coast of Wellington, New Zealand (Fig. 1). Wellington's south coast is a high energy environment, with its tidal and oceanic flows strongly influenced by Cook Strait weather [18]; water temperatures range between $11^{\circ} \mathrm{C}$ in winter to $16{ }^{\circ} \mathrm{C}$ in summer (Berman \& Bell in press, this edition). This dynamic marine environment supports high sponge abundance and diversity, particularly on the sides of gulleys and crevices, and underneath rocks, boulders and overhangs in the rocky subtidal ecosystems that characterise this coast [19]. Two widespread calcareous sponges, Leucosolenia echinata and Leucetta sp., were selected for this investigation because they are very common in the study area and their well defined exhalent oscula reduce the risk of sampling error and make sampling in situ easier.

\section{Sampling}

Seawater samples were collected in situ by SCUBA between 7 and $10 \mathrm{~m}$ depth. Samples for flow cytometry were collected in March 2009 in pairs, following the sampling method described by Pile $[8,9]$, from four specimens of each species using $5-\mathrm{ml}$ sterile plastic syringes with blunt-ended needles (Fig. 2). Sample collection consisted of water being slowly drawn from the inhalent stream at a distance of $\sim 3 \mathrm{~cm}$ from the sponge ostia, and then from the exhalent water inside the oscular aperture; care was taken to avoid contact with sponge tissue. After collection, water samples were fixed with glutaraldehyde $(0.1 \%$ final concentration), frozen in liquid nitrogen and then stored at $-80^{\circ} \mathrm{C}$ until the final flow cytometric analysis, following the protocol described by Marie et al. [20] for natural seawater samples. In preparation for flow cytometric analysis, samples were thawed to room temperature, then stained with the DNAspecific dye Hoechst $33342\left(0.2 \mu \mathrm{g} \mathrm{ml}^{-1}\right.$ final concentration $)$ for bacterial identification; samples were kept in the dark at room temperature for $1 \mathrm{~h}$ prior to analysis.

\section{Flow Cytometry Analysis}

To quantify the picoplankton populations, seawater samples were analysed using a BD LSR II SORP (Special 


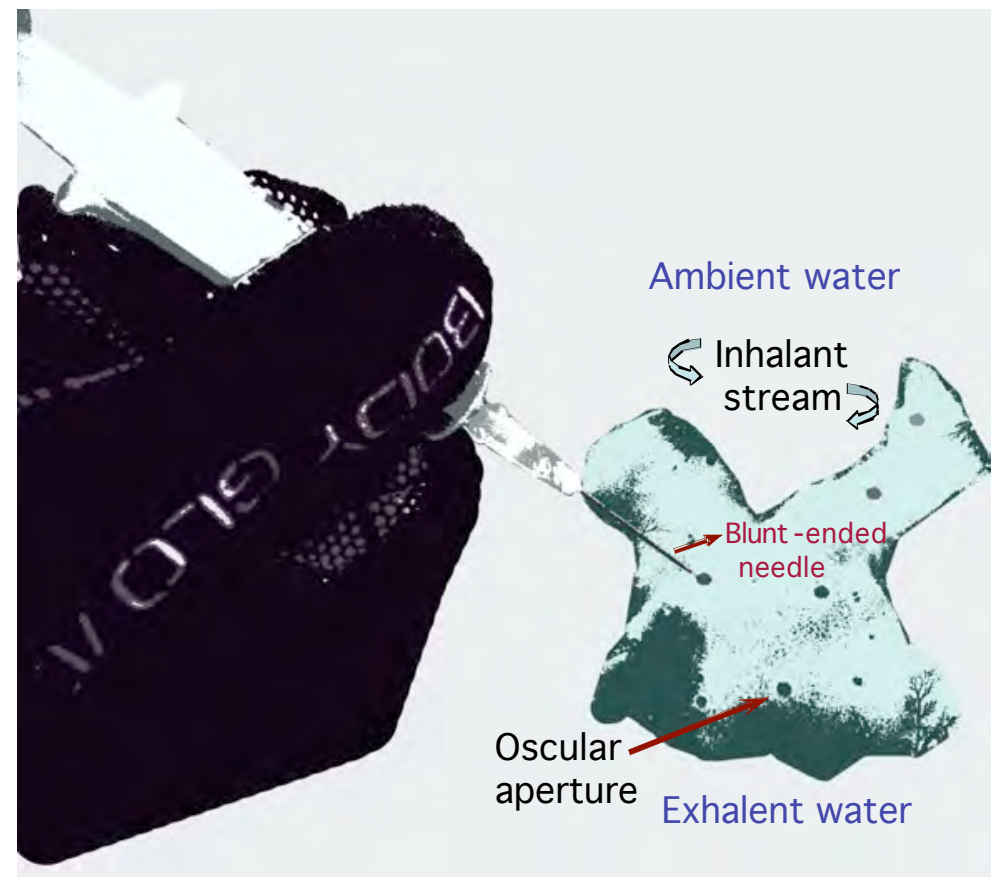

Fig. (2). Schematic representation of in situ underwater sampling method. Ambient water was collected from the inhalent current $\sim 3 \mathrm{~cm}$ from the sponge ostia, and the exhalent water was collected with a $10-\mathrm{ml}$ syringe with a blunt-ended needle from the oscular aperture.

Order Research Product) cytometer equipped with five lasers (20 mW $355 \mathrm{~nm} \mathrm{UV,} 50 \mathrm{~mW} 405 \mathrm{~nm}$ Violet, $100 \mathrm{~mW} 488$ $\mathrm{nm}$ Blue, $150 \mathrm{~mW} 532 \mathrm{~nm}$ Green, and $40 \mathrm{~mW} 633 \mathrm{~nm}$ Red lasers), at the Malaghan Institute of Medical Research in Wellington. Prior to the analysis, the LSRII SORP was calibrated using BD Cytometer Setup and Tracking Beads (Cat No. 641319). The size discrimination of the cytometer was checked using yellow-green fluorescent microspheres (1 $\mu \mathrm{m}$ diameter). Forward Scattered Light (FSC) was collected using a photodiode and Side Scattered Light (SSC) was collected using a photomultiplier tube (PMT) with a $488 \mathrm{~nm}$ band-pass filter (488/10); due to the small size of the microorganisms the cytometer was set to trigger off SSC.

The DNA-specific dye Hoechst 33342 was excited using the $20 \mathrm{~mW} 355 \mathrm{~nm}$ UV laser and the subsequent fluorescence was detected in the UV blue PMT through a $450 / 50 \mathrm{~nm}$ band-pass filter. The $100 \mathrm{~mW} 488 \mathrm{~nm}$ blue laser was used to excite chlorophyll and the emitted red fluorescence was passed through a $640 \mathrm{~nm}$ long-pass dichroic mirror and detected through a $685 / 35 \mathrm{~nm}$ band-pass filter. The $150 \mathrm{~mW}$ $532 \mathrm{~nm}$ green laser was used to better excite the phycobiliproteins and the emitted orange fluorescence was detected using a 575/26 nm band-pass filter. Two sets of flow cytometric experiments were carried out: The first set of experiments was performed in order to test the effectiveness of the sampling method. For this analysis, unstained (no Hoechst 33342 added) seawater samples from both study species were examined.

Cells of interest were identified based on being positive for Hoechst 33342 blue emission. DNA positive events were gated and viewed in a FSC vs. SSC dot plot. A "cells of interest" gate was drawn, that included events falling above $10^{2}$ on FSC and SSC to exclude noise. These events were viewed on a dot plot of orange fluorescence (y-axis) vs. red fluorescence ( $\mathrm{x}$-axis). Background noise was determined by running seawater through the cytometer to set an appropriate threshold and aid in gating.

Identification of all organisms of interest was initially based on the DNA gate. Synechococcus sp. cells were identified based on both orange and red fluorescence emission; the phycobiliproteins contained in these organisms emit a strong orange fluorescence that can be detected separately from the red fluorescence emission of their chlorophyll $[8$, 21]. Prochlorococcus sp. cells were distinguished by the presence of red florescence and the lack of orange fluorescence. Heterotrophic bacteria were identified as being DNA positive events lacking both red and orange fluorescence. When using flow cytometry, heterotrophic bacteria can only be differentiated from Prochlorococcus by staining cells with specific nucleic acid fluorochromes e.g Hoechst 33342 [16]. Finally, viruses $(0.002-0.2 \mu \mathrm{m}$ size fraction) are abundant, active components of aquatic ecosystems, but they are very difficult to quantify and classify [15]. Despite these problems, some authors have been able to distinguish different populations of viruses in natural seawater samples $[20,22,23]$ using several fluorochromes (e.g. SYBR Green). In the present study we did not quantify viruses.

Data analysis was performed using FlowJo (version 8.8.6; TreeStar, Ashland, OR), and data were presented using log-scale pseudo-colour dot plots for all parameters (SSC-A, FSC-A, orange fluorescence, red fluorescence). These plots showed three different populations of micro-organisms, Synechococcus, Prochlorococcus and heterotrophic bacteria that were mainly distinguished from the fluorescence emitted after excitation by the blue and green lasers.

\section{Data Analysis}

We applied a three-way ANOVA to determine if there was a significant difference between ambient and exhalent 
water in the cell concentrations of each type of picoplanktonic organism for each sponge species. In order to meet ANOVA assumptions of normality and homogeneity of variances, a normality test, and the Fligner-Killeen test of homogeneity of variances were performed, respectively. When assumptions were not met, we square-root transformed the data for cell counts and arcsine transformed the percentage data. A posteriori Tukey test was carried out when significant results were obtained.

The mean removal efficiency for the types of picoplankton removed by each species was calculated using the following equation:

$$
R E=\left(\frac{a m b-e x h}{a m b}\right) \times 100
$$
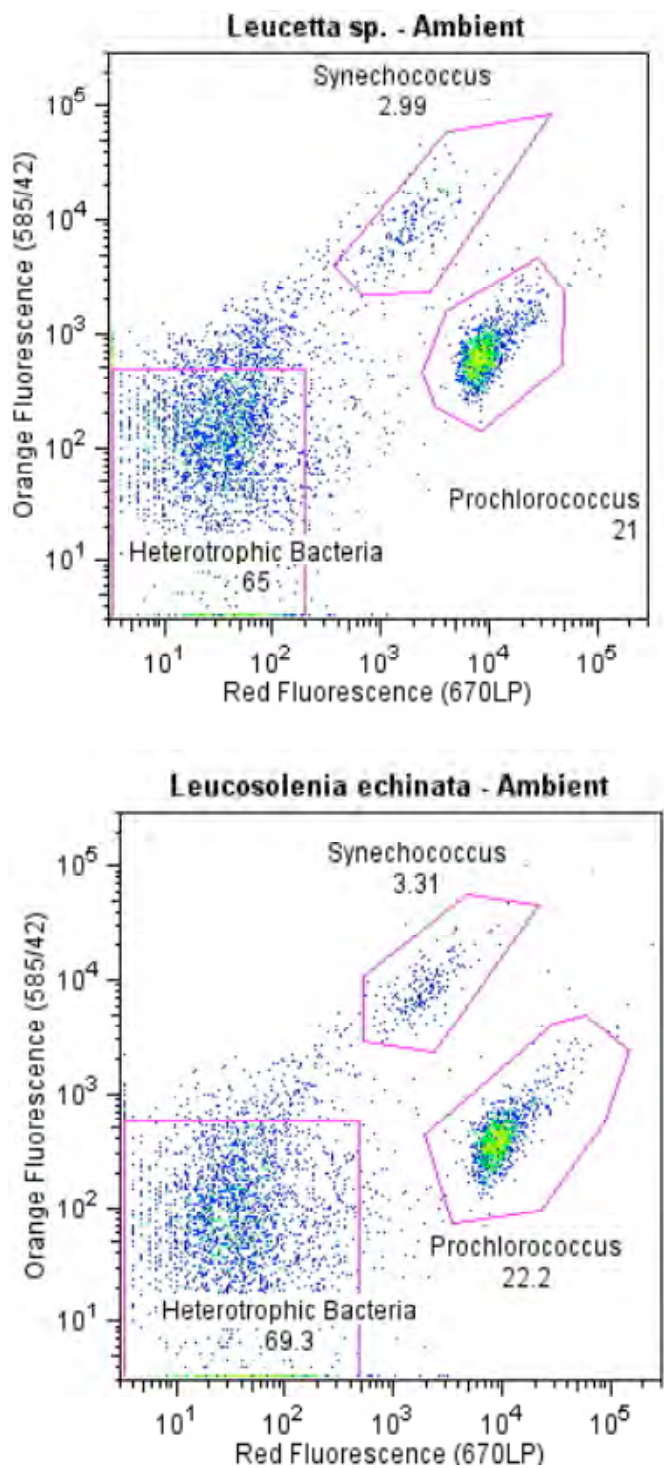

Where $R E$ is the mean removal efficiency; $a m b$ is the mean cell count for ambient water; and exh is the mean cell count for exhalent water $[9,10]$; negative retention rates resulting from exhalent cell concentrations being lower than ambient ones, obtained from three specimens, were interpreted as no retention of picoplankton and consequently changed to zero. For comparisons between the removal efficiency of the two study species and the removal of the different picoplanktonic groups, a two-way ANOVA test was applied. All statistical analyses were performed using R ver. 2.7.2 (R Development 6 Core Team 2009).

\section{RESULTS}

The results from the first set of flow cytometric experiments (refer to the methods section) identified distinct
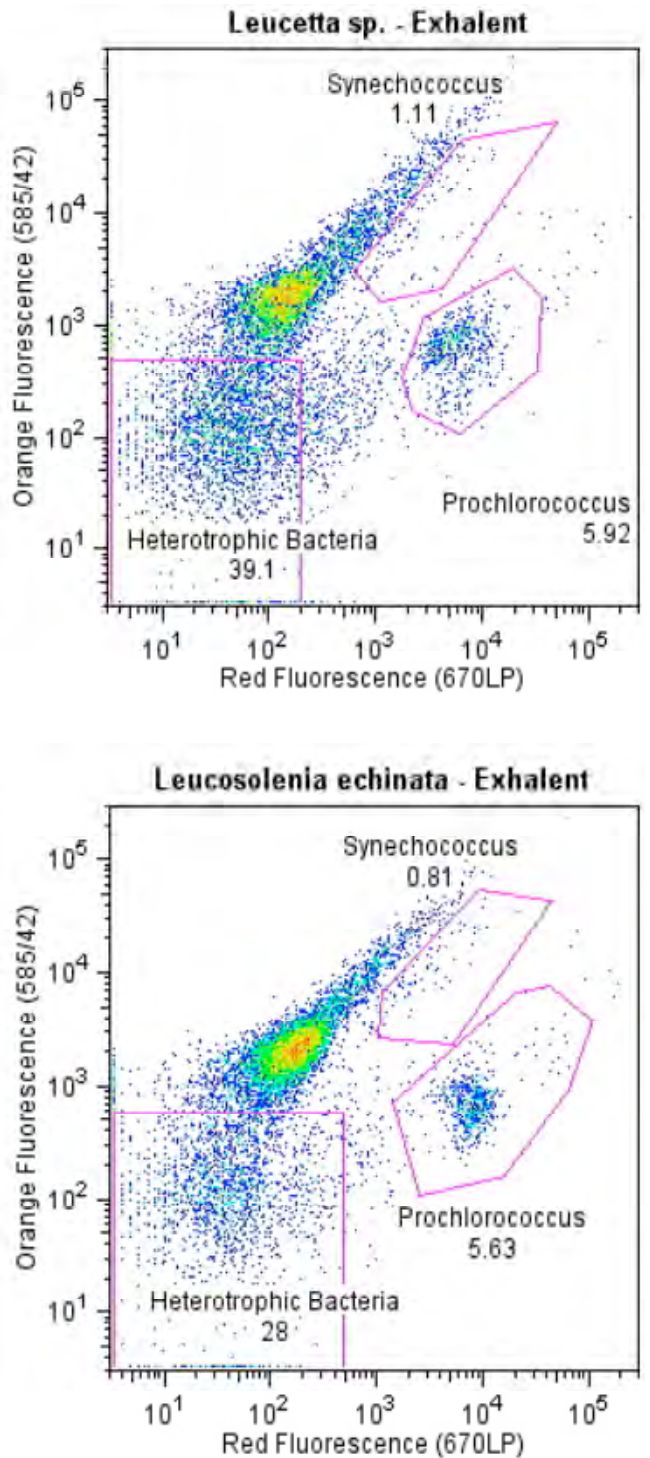

Fig. (3). Flow cytometric analysis of seawater samples collected from two species of calcareous sponges on the south coast of Wellington, NZ. Pseudo-colour dot plots illustrating picoplanktonic populations of Prochlorococcus sp., Synechococcus sp., and heterotrophic bacteria found in ambient and exhalent water samples that were identified based on the red and orange fluorescence emission profiles. DNA positive events were gated, based on a bright Hoechst 33342 blue emission, and then the populations of interest were analysed based on their orange and red emission as follows: Synechococcus exhibits bright orange and low red emission, Prochlorococcus displays bright red emission and no orange emission, and heterotrophic bacteria have no red or orange emission. 
populations of Prochlorococcus sp. and Synechococcus sp. Once these populations could be clearly detected by the flow cytometer, the second set of experiments was performed using samples stained with Hoechst. The results from this analysis yielded a third population of micro-organisms, heterotrophic bacteria, and differences in the concentration of cells between ambient and exhalent water were observed in both sponge species (Fig. 3). As a result, the diet of Leucosolenia echinata and Leucetta sp. consisted of heterotrophic bacteria, Prochlorococcus and Synechococcus. An extra population of micro-organisms appeared in the exhalant water samples from both species (Fig. 3). From the flow cytometric analysis, we suggest that in addition to background noise, there is an unidentified population of cells that may be different bacterial cells than the heterotrophic bacteria found in the ambient water, as they do not fit within the gating strategy used to analyse the populations of interest (Prochlorococcus, Synechococcus and heterotrophic bacteria). It is well known that sponges release bacterial cells different to the ones removed from the ambient water. This matter this will be further addressed on the discussion section.

\section{Picoplanktonic Concentrations in the Water Column}

We found significant differences in the number of picoplanktonic organisms between ambient and exhalent water from both Leucosolenia echinata and Leucetta sp. We also found significant differences in the cell counts between the different picoplanktonic organisms, and we detected that there was a significant difference between the sponge species and types of picoplankton (Table 1; Fig. 4A).

Table 1. Three-Way Analysis of Variance Showing Differences in Cell Concentrations per $500 \mu \mathrm{l}$ between Leucosolenia echinata and Leucetta sp., Picoplanktonic Organisms, and Environment (Ambient and Exhalent Water)

\begin{tabular}{|c|c|c|c|}
\hline Source of Variation & df & MS & F. value \\
\hline \hline Species & 1 & 3163.0 & $32.43 * *$ \\
\hline Picoplankton & 2 & 13825.4 & $141.74 * *$ \\
\hline Environment & 1 & 803.6 & $8.23 *$ \\
\hline Species + Picoplankton & 2 & 630.4 & $6.46 *$ \\
\hline Species + Environment & 1 & 35.1 & $0.36 \mathrm{NS}$ \\
\hline Picoplankton + Environment & 2 & 1136.6 & $1.4 \mathrm{NS}$ \\
\hline Species + Picoplankton + Enviro & 2 & 12.4 & $0.12 \mathrm{NS}$ \\
\hline Error & 36 & 97.5 & \\
\hline NS: $\mathrm{p}>0.05 ; * \mathrm{p}<0.01, * * \mathrm{p}<0.001$. & & & \\
\hline
\end{tabular}

The overall concentration of heterotrophic bacteria $(8.1 \pm$ $4.4 \times 10^{3}$ cells $\mathrm{ml}^{-1}$ ) was significantly higher than Prochlorococcus $\left(2.2 \pm 1.5 \times 10^{3}\right.$ cells $\left.\mathrm{ml}^{-1}\right)$ which was also significantly higher than Synechococcus $\left(3.1 \pm 2.0 \times 10^{2}\right.$ cells $\mathrm{ml}^{-1}$ ) in both ambient and exhalent water from Leucosolenia echinata and Leucetta sp. (Fig. 4B). The posteriori Tukey test showed that the cell counts of the picoplanktonic organisms were significantly higher in the ambient water surrounding both species (Tukey test $\mathrm{p}<$
0.001). Additionally, no significant differences were found in the concentrations of Prochlorococcus and Synechococcus in the ambient water surrounding both species (Tukey test $\mathrm{p}$ $>0.05$ ), but the concentration of heterotrophic bacteria was significantly higher (Tukey test $p<0.001$ ) in ambient water
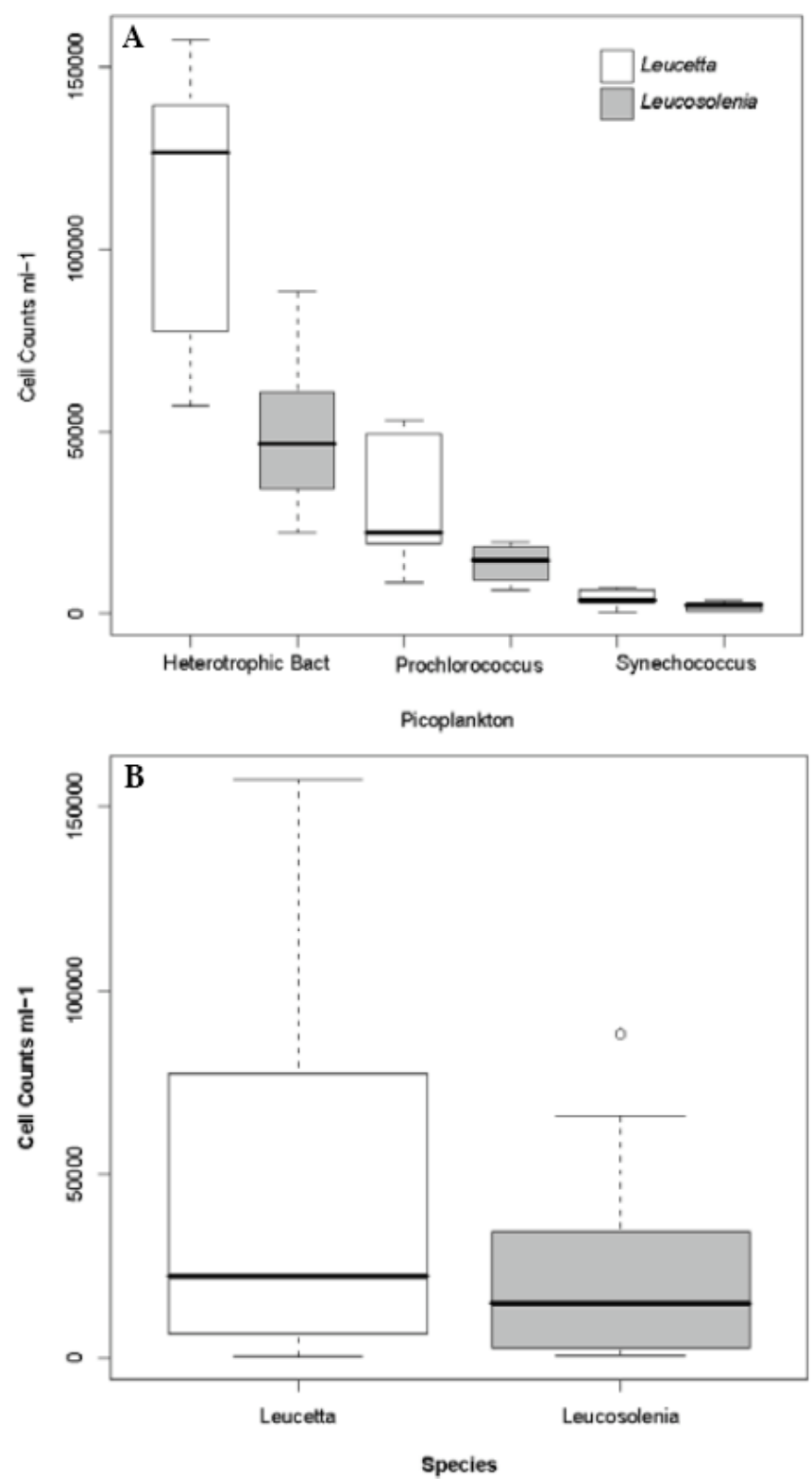

Fig. (4). Box plots showing mean cell counts of (A) differences between each group of picoplanktonic organism (heterotrophic bacteria, Synechococcus, Prochlorococcus) measured for both sponge species, and (B) picoplanktonic organisms quantified from the water surrounding both study species.

surrounding Leucetta sp. $\left(118818 \pm 41533\right.$ cells $\left.\mathrm{ml}^{-1}\right)$ than in the water surrounding Leucosolenia echinata (51625 \pm 12894 cells ml${ }^{-1}$ ) (Fig. 5A, B).

\section{Sponge Prey Removal}

Both sponge species had similar overall removal efficiencies (two-way ANOVA, $F_{1,18}=0.89, \mathrm{p}>0.05$ ), 
though we detected significant differences in the removal rates of the three types of picoplankton by each species (Table 2; Fig. 6A, B). The posteriori Tukey test revealed that the removal efficiency of heterotrophic bacteria (10-25\%) was significantly lower than that on Prochlorococcus (5257\%) and Synechococcus (53-55\%) for both species (Fig. 7).

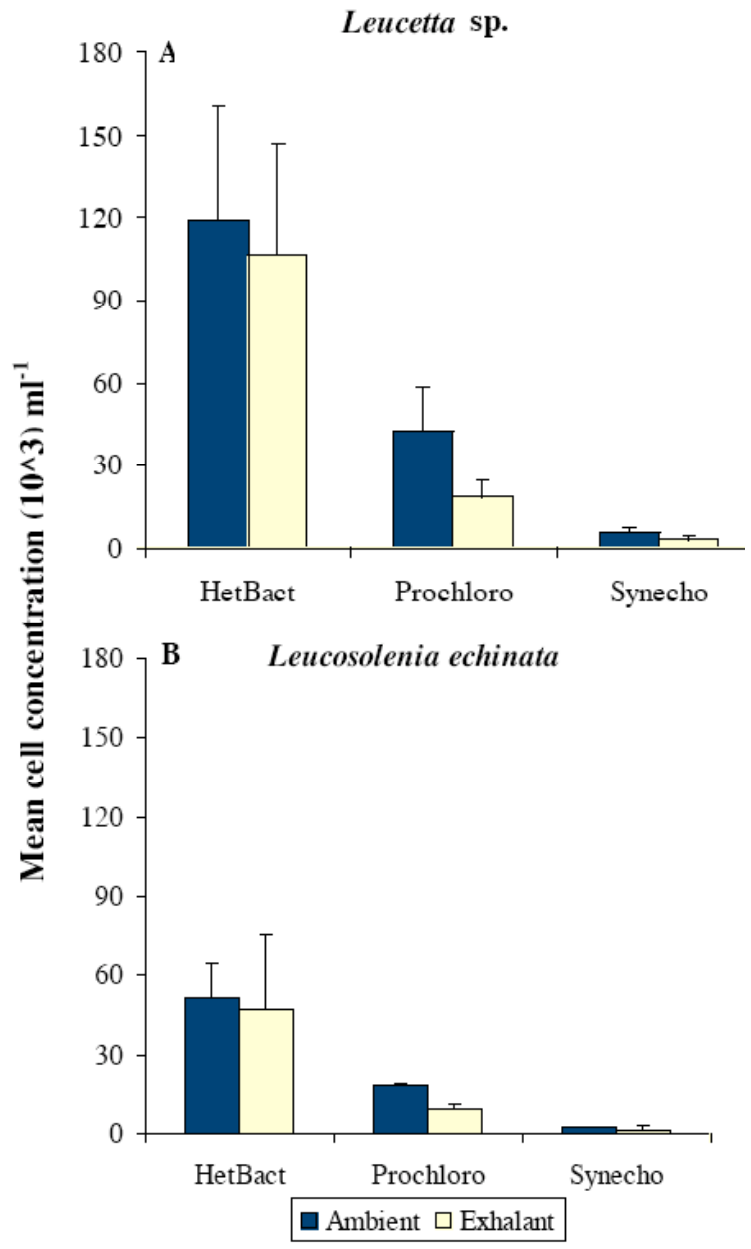

Fig. (5). Mean cell counts for each group of picoplanktonic organism found in ambient and exhalent water from Leucosolenia echinata and Leucetta sp.

Table 2. Two-Way Analysis of Variance Showing Differences in the Removal Efficiency (Percentage Removed) of both Sponge Species and Types of Picoplankton. There was a Significant Difference in the Removal Efficiency of the Three Picoplanktonic Organisms (Heterotrophic Bacteria, Prochlorococcus and Synechococcus) by Leucosolenia echinata and Leucetta sp.

\begin{tabular}{|c|c|c|c|}
\hline Source of Variation & df & MS & F. value \\
\hline \hline Species & 1 & 5.1 & 0.89 NS \\
\hline Picoplankton & 2 & 2005.3 & $6.46^{*}$ \\
\hline Species + Picoplankton & 2 & 0.22 & $0.79 \mathrm{NS}$ \\
\hline Error & 18 & 310.4 & \\
\hline
\end{tabular}

NS: $p>0.05 ; * p<0.01$.
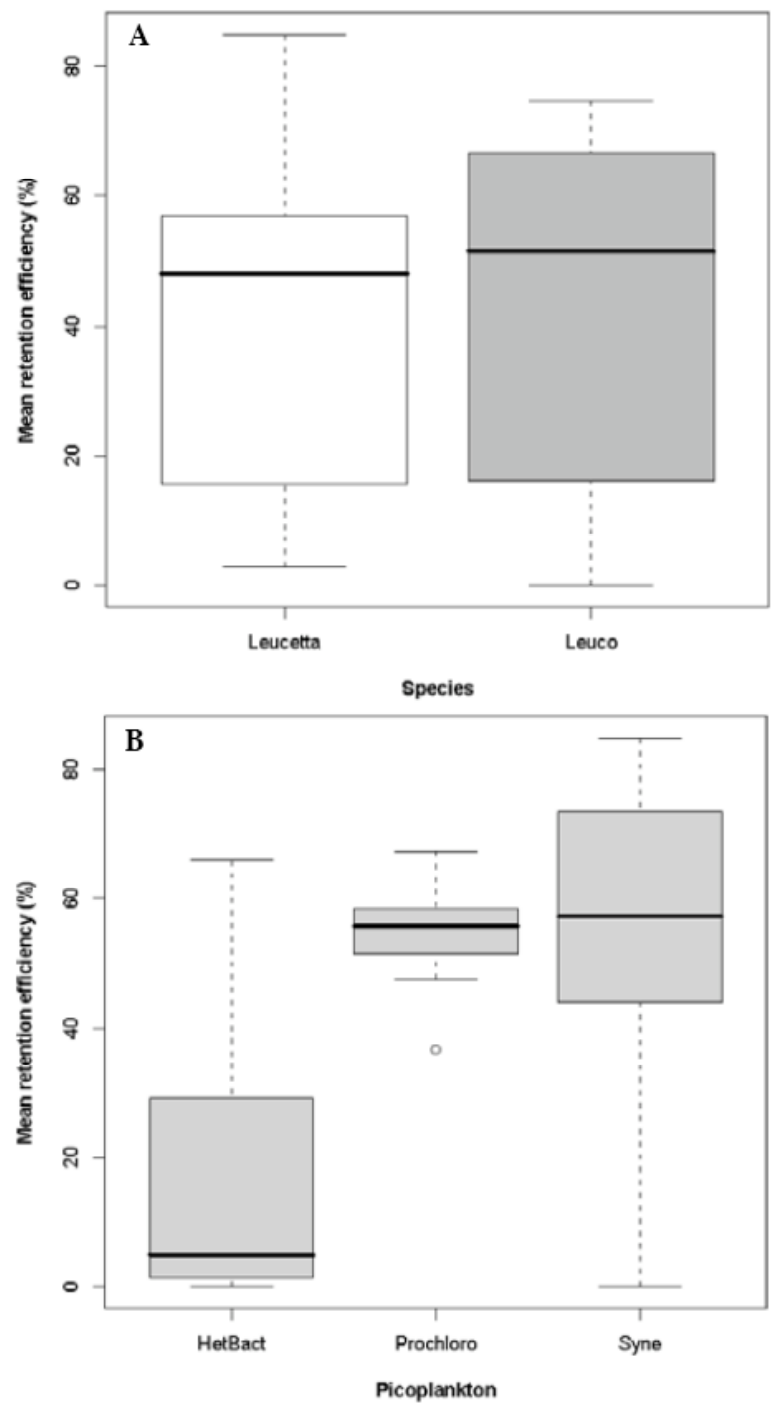

Fig. (6). Box plots showing mean removal efficiency expressed as (A) percentage of picoplankton retained by both sponge species and (B) percentage retained of each type of picoplanktonic organism per sponge species.

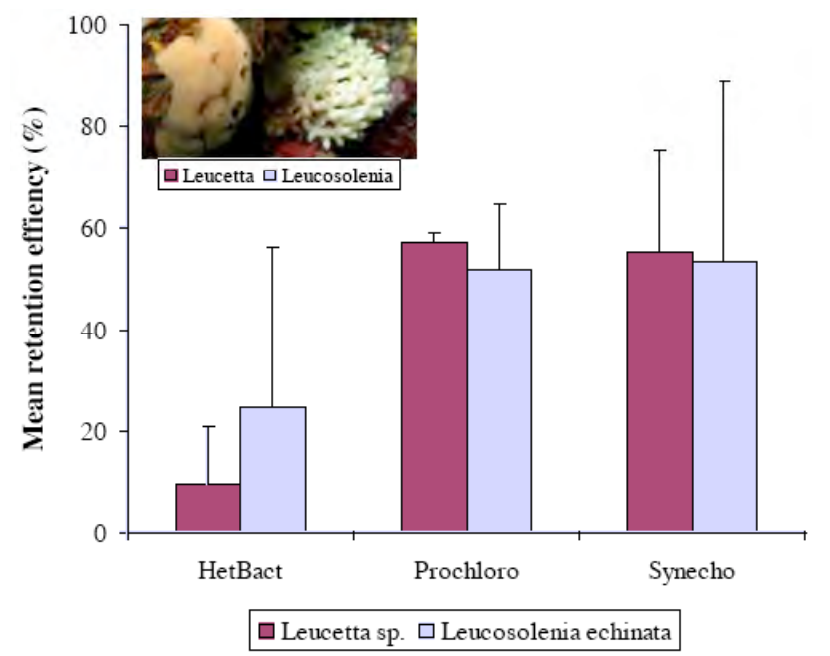

Fig. (7). Retention efficiency, expressed as percentage removal of each group of picoplanktonic organism in Leucosolenia echinata and Leucetta sp. 


\section{DISCUSSION}

Our study is the first to investigate the natural diet of calcareous sponges in temperate rocky subtidal reefs using flow cytometry. The results for our two calcareous species showed lower removal efficiencies, particularly on heterotrophic bacteria, and overall lower removal efficiencies on Prochlorococcus and Synechococcus compared to published data for other temperate demosponges [9-11]. Also, we found a much higher concentration of heterotrophic bacterial cells in the ambient water around Leucetta sp. than in the water around Leucosolenia echinata, which was surprising as the water samples were collected on the same day from the same study site and type of habitat.

\section{Removal Efficiency of Calcareous Sponges}

Direct measurements have corroborated that both tropical and temperate sponges, as well as freshwater sponges, have high capture rates of picoplankton [24]. The results from our study confirm the effectiveness of flow cytometry in analysing the diet composition of sponges. The retention efficiencies of the two calcareous sponges we studied ranged between 10 and $57 \%$, for the same picoplanktonic organisms analysed in previous studies using flow cytometry. These removal efficiencies are lower than those obtained in situ from temperate demosponges in recent studies $[10,11]$, where removal efficiencies range between $60 \%$ and $90 \%$; these are similar to the removal rates reported for tropical sponges $[9,25]$. The removal rates we obtained may have been influenced, most importantly, by the fact that the study species are calcareous sponges and the majority of available data on removal rates are for demosponges. The possession of a skeleton made of calcium carbonate makes the Calcarea distinctive with respect to the other groups of sponges [26] and in addition to their differences in spicule composition, water flow in calcareous sponges differs from demosponges due to their body construction and aquiferous system [27]. These characteristics might have an influence on the removal efficiencies and types of micro-organisms that these sponges filter from the water column, though specific mechanisms of how these characteristics translate to removal differences remain unknown [28, 29].

Francis and Poirrier [30] studied the particle uptake of two freshwater sponges and suggested that particle selection is probably determined by the rate at which the sponge can degrade particles and derive nutrients from them, as well as by the general availability of picoplankton. Although our results showed higher removal rates of Prochlorococcus and Synechococcus by both species, these percentages were lower than those obtained for other temperate demosponges. In their study of the metabolism of the calcareous sponge Clathrina clathrus from the Mediterranean, Burlando et al. [31] suggested that biochemical variations (e.g. tissue sugar content, protein and lipid concentration) seemed to be related both to changes in seasonal feeding and to metabolic physiological responses caused by cyclic climatic events. These findings, in conjunction with those of Wilkinson [32], are relevant to our study as we propose that calcareous sponges may potentially degrade particles at lower rates than demosponges and that this difference may be related to physiological characteristics and complexity of the aquifeous system [32].
We measured retention efficiencies of between $10 \%$ and $25 \%$ for heterotrophic bacteria in both study species. These values are markedly lower than those previously reported for temperate demosponges, where retention efficiencies of heterotrophic bacteria range from $43-90 \%[8,10,11,33]$. In Wilkinson's [13] work, the percentage of heterotrophic bacteria removed by the calcareous sponge Pericharax heteroraphis was $95.5 \%$. Although this species is a tropical sponge, it is the only removal efficiency value that has been measured for a calcareous sponge that we can compare with our results. It is possible that the low removal efficiencies obtained from our results may have also been influenced by the time of year when samples were collected and by a high concentration of micro-organisms present in the water column that these sponges may only need to remove a small fraction of them in order to meet their nutritional requirements. On the other hand, total uptake may be influenced by the patchy distribution of the micro-organisms in the water column; low nutrient concentrations in the water column; or short term physical events such as waves and storms that can affect food uptake and availability [8].

There is little information available on the ecology and physiology of calcareous sponges. Leys \& Eerkes-Medrano [28] investigated particle uptake in a calcareous sponge by feeding sponges with bacteria and latex microspheres, both in situ and in vitro. Although their results do not consider the feeding ecology of calcareous sponges, they do provide a detailed description of the physiological mechanisms of feeding in these sponges and the size of particles that they can effectively remove. These findings are relevant to our study as they observed uptake of $1-\mu \mathrm{m}$ sized natural bacteria, similar to our findings where we measured the removal of micro-organisms of $1 \mu \mathrm{m}$ or less in size from the ambient water as shown in our flow cytometric plots (see results section for more detail). In conclusion, we demonstrate that calcareous sponges feed on picoplankton (plankton $<2 \mu \mathrm{m}$ ), similar to data previously published for demosponges.

The additional population that appeared in the exhalent water can be explained in light of the existing literature. It is known that the internal tissue of marine sponges is the habitat of symbiotic bacteria [32, 34]. Wilkinson et al. [13] in their study of four species of marine sponges, reported evidence that sponges are able to discriminate between bacteria normally found in the ambient water (regarded as food), and symbiotic bacteria isolated from the sponges themselves. They showed that symbiotic bacteria passed readily through the sponge, whereas seawater bacteria were retained. Similarly, Gili et al. [35] reported that bacterial colonies growing in plates with exhaled water samples presented different forms and colours than the bacterial colonies growing in plates with ambient water samples suggesting that the nature of the exhaled bacteria was different from the inhaled bacteria. In the case of our study species, future work is needed to investigate whether or not the released cells are live micro-organisms and if these cells are symbiotic bacteria or other types of bacteria.

\section{CONCLUSION}

We conclude that both sponge species we studied are efficient feeders on Synechococcus sp. and Prochlorococcus 
sp. with removal efficiencies ranging between $55 \%$ and $57 \%$, respectively. Prochlorococcus and Synechococcus cellremoval rates were higher than those for heterotrophic bacteria in both study species, suggesting a higher grazing efficiency upon these prey types and a markedly lower removal efficiency of heterotrophic bacteria. Comparison of removal efficiencies between species and classes is difficult due to the variability within each species and group [11]. Future studies are needed to evaluate if the ambient heterotrophic bacterial concentrations change through time and if there is a correlation between the concentration of dissolved nutrients in the water and the concentration of these picoplanktonic organisms. Aspects of the nutritional ecology of calcareous sponges are yet to be described, and related to seasonality and availability of micro-planktonic populations in temperate ecosystems, but this will be a focus of our future work.

\section{ACKNOWLEDGEMENTS}

Alejandra Perea-Blázquez is grateful to Victoria University of Wellington and NZPSAA for providing funding for flow cytometry training, a $\mathrm{PhD}$ scholarship and further financial assistance through the Hardship Fund. We acknowledge Dr. Adele Pile for her invaluable assistance with the underwater sampling technique and flow cytometry training, and Dr. Michelle Kelly and Jade Berman for their taxonomic assistance. We are also, grateful to Benjamin Magaña-Rodriguez, Jade Berman and Daniela Díaz-Guisado for their assistance with field work. Benjamin MaganaRodriguez also assisted with the compilation of the site map and Alejandro Perez-Matus assisted with the statistical analyses. The Department of Conservation is also acknowledged for permitting field work within the Taputeranga Marine Reserve (permit docDM-336985).

\section{REFERENCES}

[1] Orejas C, Gili JM, Arntz WE, et al. Benthic suspension feeders, key players in Antartic marine ecosystems? Contrib Sci 2000; 1: 299-311.

[2] Gili J-M, Coma R. Benthic suspension feeders: their paramount role in littoral marine food webs. Trends Ecol Evol 1998; 13: 31621.

[3] Pile AJ, Young CM. The natural diet of a hexactinellid sponge: Benthic-pelagic coupling in a deep-sea microbial food web. DeepSea Res 2006; 53: 1148-56.

[4] Bell JJ. The functional roles of marine sponges. Estuar Coast Shelf Sci 2008; 79: 341-53

[5] Wulff J. Assessing and monitoring coral reef sponges: why and How? Bull Mar Sci 2001; 69(2): 831-46.

[6] Díaz MC, Rüztler K. Sponges: an essential component of Caribbean coral reefs. Bull Mar Sci 2001; 69: 535-46.

[7] Jiménez E, Ribes M. Sponges as a source of dissolved inorganic nitrogen: Nitritication mediated by temperate sponges. Limnol Oceanogr 2007; 52: 948-58.

[8] Pile AJ, Patterson MR, Witman JD. In situ grazing on plankton $<10 \mu \mathrm{m}$ by the boreal sponge Mycale lingua. Mar Ecol Prog Ser 1996; 141: 95-102.

[9] Pile AJ, Finding Reiswig's missing carbon: quantification of sponge feeding using dual-beam cytometry, in Proceedings of the $8^{\text {th }}$ International Coral Reef Symposium, Lessios HA, Macintyre IG, Eds. Smithsonian Tropical Research, Panama 1997; vol. 2: pp. 1403-10.

[10] Yahel G, Marie D, Genin A. InEx- a direct in situ method to measure filtration rates, nutrition, and metabolism of active suspension feeders. Limnol Oceanogr 2005; 3: 46-58.
[11] Ribes M, Coma R, Gili J-M. Natural diet and grazing rate of the temperate sponge Dysidea avara (Demospongiae, Dendroceratida) throughout an annual cycle. Mar Ecol Prog Ser 1999; 176: 179-90.

[12] Reiswig HM. Bacteria as food for temperate-water marine sponges. Can J Zool 1975; 53: 582-89.

[13] Wilkinson CR, Garrone R, Vacelet J. Marine sponges discriminate between food bacteria and bacterial symbionts: electron microscope radioautography and in situ evidence. Proc R Soc Lond B 1984; 220: 519-28.

[14] Marie D, Simon N, Guillou L, et al. DNA/RNA analysis of phytoplankton by flow cytometry. Curr Protoc Cytom 2000; Chapter 11: Unit 11.2.

[15] Vives-Rego J, Lebaron P, Caron GN-v. Current and future applications of flow cytometry in aquatic microbiology. FEMS Microbiol Rev 2000; 24: 429-48.

[16] Marie D, Partensky F, Jacquet S, et al. Enumeration and cell cycle analysis of natural populations of marine picoplankton by flow cytometry using the nucleic acid stain SYBR Green I. Appl Environ Microbiol 1997; 63: 186-93.

[17] Chisholm S, Frankel SL, Goericke R, et al. Prochlorococcus marinus nov. gen. nov. sp.: an oxyphototrophic marine prokayote contaning divinyl chlorophyll $a$ and $b$. Arch Microbiol 1992; 157: 297-300.

[18] Carter L. Below low tide - a seabed in motion. In: Gardner J, Ed. The Taputeranga marine reserve. Wellington: First Eds Ltd; 2008; p. 532 .

[19] Berman J, Perea-Blázquez A, Kelly M, et al. Sponges of the Wellington south coast. In: Gardner J, Bell J, Eds. The Taputeranga Marine Reserve. Wellington: First Eds Ltd; 2008; p. 532 .

[20] Marie D, Partensky F, Vaulot D, et al. Enumeration of phytoplankton, bacteria, and viruses in marine samples. Curr Protoc Cytom 1999; Chapter 11: Unit 11.11.

[21] Campbell L, Nolla HA, Vaulot D. The importance of Prochlorococcus to community structure in Central North Pacific Ocean. Limnol Oceanogr 1994; 39: 954-61.

[22] Marie D, Brussaard CPD, Thyrhaug R, et al. Enumeration of marine viruses in culture and natural samples by flow cytometry. Appl Environ Microbiol 1999; 65: 45-52.

[23] Patten NL, Seymour JR, Mitchell JG. Flow cytometric analysis of virus-like particles and heterotrophic bacteria within coralassociated reef water. J Mar Biol Ass UK 2006; 86: 563-66.

[24] Gili J-M, Coma R. Benthic suspension feeders: their paramount role in littoral marine food webs. Trends Ecol Evol 1998; 13: 31621.

[25] Reiswig HM. Particle feeding in natural populations of three marine Demosponges. Biol Bull 1971; 141: 568-91.

[26] Manuel M, Borojevic R, Boury-Esnault N, et al. Calss Calcarea Bowerbank, 1864. In: Hooper JNA, Ed. Systema Porifera: A Guide to the Classification of Sponges. New York: Kluwer Academic/ Plenum Publishers; 2002; p. 1708.

[27] Manuel M. Phylogeny and evolution of calcareous sponges1. Can J Zool 2006; 84: 225-41.

[28] Leys SP, Eerkes-Medrano DI. Feeding in a calcareous sponge: Particle uptake by pseudopodia. Biol Bull 2006; 211: 157-71.

[29] Yahel G, Eerkes-Medrano D, Leys SP. Size independent selective filtration of ultraplankton by hexactinellid glass sponges. Aquat Microb Ecol 2006; 45: 181-94.

[30] Francis JC, Poirrier MA. Particle uptake in two fresh-water sponge species, Ephydatia fluviatilis and Spongilla alba (Porifera: Spongillidae). Trans Am Microsc Soc 1986; 105: 11-20.

[31] Burlando B, Bavestrello G, Arillo A. Seasonal changes in the metabolism of the calcareous sponges Clathrina clathrus (Schmidt). Comp Biochem Physiol 1992; 101: 341-4.

[32] Wilkinson CR. Microbial associations in sponges. I. Ecology, physiology and microbial populations of coral reef sponges. Mar Biol 1978; 49: 161-7.

[33] Pile AJ. Overlap in diet between co-occurring active suspension feeders on tropical and temperate reefs. Bull Mar Sci 1995; 76: 743-9.

[34] Vacelet J. Étude en microscopie électronique de l'association entre bactéries et spongiaires du genre Verongia (Dictyoceratida). J Microsc Biol Cell 1975; 23: 271-88. 
[35] Gili J-M, Bibiloni MA, Montserrat A. Tasas de filtración y retención de bacterias "in situ" de tres especies de esponjas litorales. Estudio preliminar. Misc Zool 1984; 8: 13-21 (in Spanish).

Received: June 02, 2009

Revised: November 21, 2009

Accepted: January 14, 2010

(C) Perea-Blázquez et al.; Licensee Bentham Open.

This is an open access article licensed under the terms of the Creative Commons Attribution Non-Commercial License (http://creativecommons.org/licenses/by$\mathrm{nc} / 3.0 /$ ), which permits unrestricted, non-commercial use, distribution and reproduction in any medium, provided the work is properly cited. 